\title{
Prediction of Stature from Somatometry of the Left Hand in Igbos, Nigeria
}

Ekezie $\mathrm{J}^{1^{*}}$, Anibeze $\mathrm{CIP}^{2}$, Anyanwu $\mathrm{GE}^{3}$ and Uloneme $\mathbf{G C}^{4}$

${ }^{1}$ Department of Prosthetics and Orthotics, School of Health Technology, Federal University of Technology, Owerri, Nigeria ${ }^{2}$ Department of Anatomy, Faculty of Basic Medical Sciences, Enugu State University of Science and Technology Enugu, Nigeria

${ }^{3}$ Department of Anatomy, College of Medicine, University of Nigeria, Enugu Campus, Nigeria

${ }^{4}$ Department of Anatomy \& Neurobiology, College of Medicine and Health Sciences, Imo State University Owerri, Nigeria

\begin{abstract}
The identification of a person is based on some biological profiles. Stature is one of such; its prediction plays important role in forensic investigation. An attempt was made to establish the stature of the lgbos using left finger lengths, hand length and hand breadth. The correlation between stature and hand dimensions was studied. Which of the hand segments is the best to predict the stature of the lgbos? 88 males and 123 females were included in this study after obtaining informed consent. Measurements of hand segments were taken using Sliding Caliper and the height was recorded using Anthropometer. The data were subjected for statistical analysis. Significant correlation between stature and the entire hand dimensions was established except hand breadth (HB) in the females. Independent linear regression equations to calculate the stature were obtained for hand segments in both genders put together, in males and females separately. Hand length had the best prediction power in both genders put together as well as in the females. In males, the best prediction power was observed in fourth digit length followed by hand length. The multiple linear regression model generated for both genders put together performed better than the simple linear regression models for the males or females.
\end{abstract}

Keywords: Stature; Hand length; Digit length; Anthropometer; Sliding caliper

\section{Introduction}

Stature is a composite of linear dimensions of the skull, vertebral column (spine), pelvis, thigh, legs [1] and some parts of the foot [2]. It has been estimated in many populations using regression formulas derived from hand dimensions [3-17] and also from other body segments [11,18-31]. It is one of the most important anthropometric parameter for identification of an individual [1,21,29,32,33]. Estimated stature from hand length, phalangeal length as well as from inked print of the aforementioned variables has been performed [5]. Result from such study indicated no significant difference between the hand variables and the hand prints variables but revealed significant correlations between stature and the all variables.

Among the Igbos of Nigeria, much work has not been done in forensic/physical anthropology. We therefore undertake this study to generate reference data for the consumption of the scientist and the general populace using somatometry of the left hands (palmar surface).

\section{Materials and Method}

The study was based on a random sampling of 211 Subjects (females $\mathrm{n}=123$, and males $\mathrm{n}=88$ ) aged $16-45$ years of the Igbo ethnic group of Nigeria, and attention was paid to stature estimation using left hand somatometry after obtaining an informed consent.

\section{Study location and duration}

The study was conducted in Imo State, Nigeria; it covered a period of ten (10) months.

\section{Demographics}

Information on age, sex, and state of origin were documented.

\section{Exclusion criteria}

Subjects who were not of Igbo origin were excluded from the study. Also subjects who were pregnant or subjects having any deformity affecting the musculoskeletal system were not allowed to participate in the study. Also hand dimension which were not significantly correlated with stature was not used to regress stature.

\section{Anthropometrics}

Stature was measured following standard protocols [34] and the following hand measurements were taken in centimeters using a sliding caliper following the procedure of $[3,6,7]$ but on the left hand.

Stature (Y): The height was measured to the nearest $0.1 \mathrm{~cm}$ using an Anthropometer with subjects standing without shoes with the heels held together, toes apart, and the head held in the Frankfort plane $[29,34]$.

Hand length (HL): is the linear distance $(\mathrm{cm})$ between the distal wrist crease and the distal end of the longest finger [5,29] (Figure 1).

Hand breath (HB): is the linear distance between the middle projecting part of the thumb in adducted position and the corresponding part of the ulna side of the hand [12,15] (Figure 2).

- $\quad 1^{\text {st }}$ digit length $\left(1^{\mathrm{st}} \mathrm{DL}\right)$ is the linear distance $(\mathrm{cm})$ between the proximal digital crease and the distal end of the first finger.

- $\quad 2^{\text {nd }}$ digit length $\left(2^{\text {nd }} \mathrm{DL}\right)$ is the linear distance $(\mathrm{cm})$ between the proximal digital crease and the distal end of the second finger.

- $\quad 3^{\text {rd }}$ digit length $\left(3^{\text {rd }} \mathrm{DL}\right)$ is the linear distance $(\mathrm{cm})$ between

*Corresponding author: Ekezie Jervas, Department of Prosthetics and Orthotics, School of Health Technology, Federal University of Technology, P.M.B 1526 Owerri, Nigeria, Tel: +234 806 5430037; E-mail ekeziejervas@gmail.com

Received February 27, 2015; Accepted June 27, 2015; Published July 03, 2015

Citation: Ekezie J, Anibeze CIP, Anyanwu GE, Uloneme GC (2015) Prediction of Stature from Somatometry of the Left Hand in Igbos, Nigeria. J Forensic Res S1: 005 doi:10.4172/2157-7145.S3-005

Copyright: (C) 2015 Ekezie J, et al. This is an open-access article distributed under the terms of the Creative Commons Attribution License, which permits unrestricted use, distribution, and reproduction in any medium, provided the original author and source are credited. 


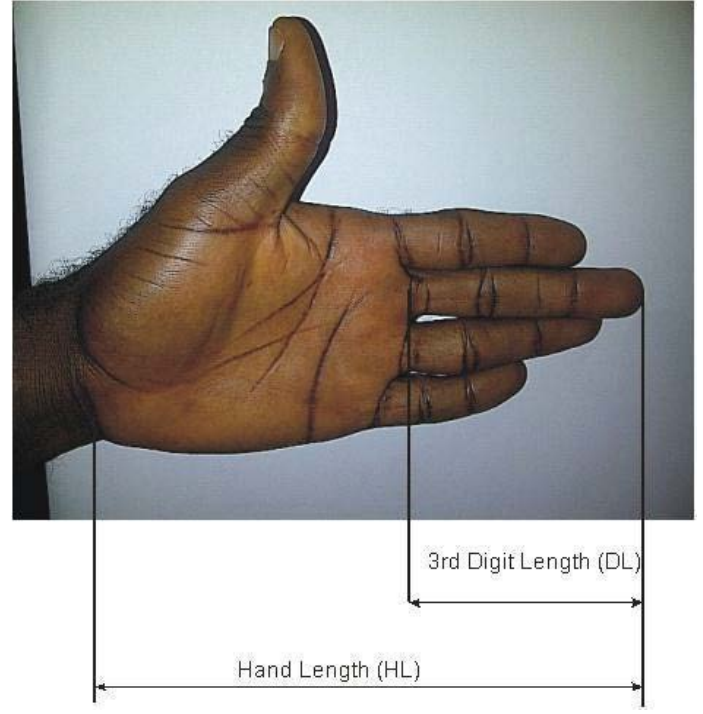

Figure 1: Shows the segmental landmarks for Hand length $(\mathrm{HL})$, and 3rd digit length $\left(3^{\text {rd }} \mathrm{DL}\right)$

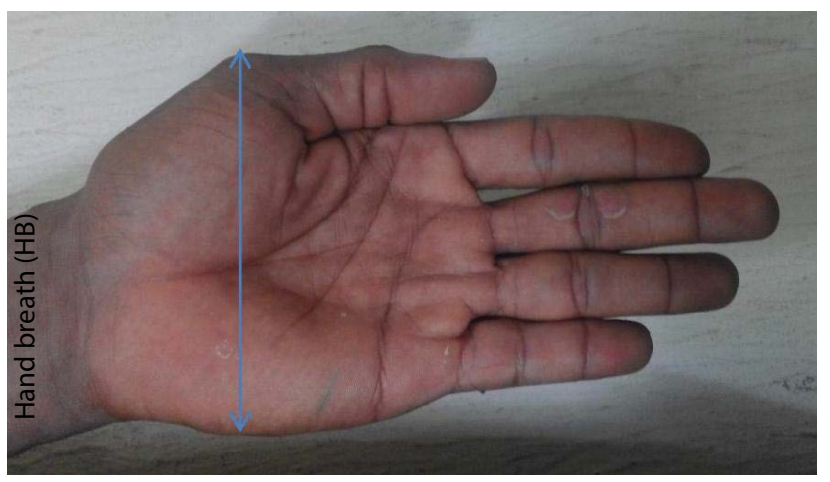

Figure 2: Shows the segmental landmarks for the Hand breath (HB).

the proximal digital crease and the distal end of the third finger see Figure 1.

- $\quad 4^{\text {th }}$ digit length $\left(4^{\text {th }} \mathrm{DL}\right)$ is the linear distance $(\mathrm{cm})$ between the proximal digital crease and the distal end of the fourth finger.

- $\quad 5^{\text {th }}$ digit length $\left(5^{\text {th }} \mathrm{DL}\right)$ is the linear distance $(\mathrm{cm})$ between the proximal digital crease and the distal end of the fifth finger.

\section{Data Presentation and Analysis}

The data analysis was carried out using statistical package for social sciences (SPSS 17.0 software). In summarizing the data, the Minimum, Maximum, Mean and Standard deviations were estimated and presented. A comparison of difference of variable in females and males left hand dimensions was performed. Pearson correlation was then applied to test the relationship between stature and hand dimensions and the results are presented for both genders together, males and females.

The prediction function was derived through linear regression for each of the measurement with stature for both genders together, males and females separately. The presentation also provides the values of Constant, Regression coefficient, Percentage variation explained $\left(\mathrm{R}_{2}\right)$ and Significance of regression coefficient. The multiple linear regression models [26] with the explanatory variables or repressors'- left hand dimensions were proposed as a statistical model to explain the total variation. The generated regression formula from a stepwise analysis is such that stature $(y)=a$ (constant $)+b_{1}$ (regression coefficient for the first variable) $x_{1}$ (first variable) $+b_{2}$ (regression coefficient for the second variable) $x_{2}$ (second variable) $+\ldots \ldots b_{n}$ (regression coefficient for the nth variable) $\mathrm{xn}$ (nth variable), with this we can estimate stature from hand dimensions. In the results that follow, $\mathrm{R}$ indicates the multiple correlation coefficient value [28]. It is one of the measures used for model adequacy. It is the correlation between the observed values and the fitted values for the dependent variable. $R_{2}$ explains the percentage that a dimension contributes to the variation in the dependent variable (stature). $\mathrm{R}_{2}$ adjusted is used to compare the regression models containing different number of explanatory variables (hand segments). The standard error of estimate (SEE) is the error that may arise from estimating stature. It predicts the deviation of estimated stature from the actual stature [27]. A low value of SEE is indicative of the greater reliability of prediction from a particular measurement while a higher value denotes less reliability.

\section{Result}

We can see the standard deviation, the mean, the maximum and minimum values of the anthropometric variables in both genders put together (Table 1). Overall, males are more varied with higher mean values than females. All the anthropometric dimensions measured directly showed statistically significant differences between females and males: HL, HB and $1^{\text {st }} \mathrm{DL}(\mathrm{p}<0.0001), 2^{\text {nd }} \mathrm{DL}$ and $5^{\text {th }} \mathrm{DL}(\mathrm{p}<0.002)$, $3^{\text {rd }} \mathrm{DL}(\mathrm{p}<0.001)$, with males having a higher mean value than females (Table 2).

The correlation coefficient between stature and the left hand dimensions in both genders put together, females and males respectively was found to be statistically significant and positive, indicating a strong relationship between stature and left hand dimensions, except for hand breadth $(\mathrm{HB})$ in females. The highest positive correlation was observed in hand length $(\mathrm{HL}), \mathrm{r}=0.727$ while the least was observe in $5^{\text {th }}$ digit length $\left(5^{\text {th }} \mathrm{DL}\right) \mathrm{r}=0.504$ in both genders put together (Table 3$)$. For the females, the least significant correlation was observed in the $5^{\text {th }}$ $\mathrm{DL}, \mathrm{r}=0.397$ while the highest value was obtained in $\mathrm{HL}, \mathrm{r}=0$.638. In the male population, the least significant correlation was observed in $\mathrm{HB}, \mathrm{r}=0.431$ while the highest was observed in $4^{\text {th }} \mathrm{DL}, \mathrm{r}=0.633$. The Constant, Regression coefficient and Variation explained $\left(\mathrm{R}^{2}\right)$ derived for each of the left hand measurements with stature are shown in Table 4 for both genders put together, and in Table 5 for females and males respectively. The regression coefficients were significant indicating that they are contributing for the prediction of stature. The variation explained $\left(R^{2} \times 100\right)$ showed that it ranges from $25.4 \%$ to $52.8 \%$ in both genders. For the females the variation explained ranged from $15.8 \%$ to $40.7 \%$. In the males, the variation explained ranged from $18.6 \%$ to $40.1 \%$.

Table 6 shows the values for $\mathrm{R}, \mathrm{R}_{2}$, Adjusted $\mathrm{R}_{2}$, and SEE of the left hand variables in both genders put together, females and males respectively. In both genders together, one multiple linear regression models was constructed using $1^{\text {st }} \mathrm{DL}$ and $2^{\text {nd }} \mathrm{DL}$ and this has the highest values for the coefficient of determination $\mathrm{R}_{2}$ as $0.505, \mathrm{R}_{2}$ Adjusted as 0.495 and multiple correlation coefficient $\mathrm{R}$ as 0.711 with a lower SEE as 6.158. Seven simple linear regression models were also constructed. The best simple linear regression model was developed using HL and this 
Citation: Ekezie J, Anibeze CIP, Anyanwu GE, Uloneme GC (2015) Prediction of Stature from Somatometry of the Left Hand in Igbos, Nigeria. J Forensic Res S1: 005 doi:10.4172/2157-7145.S3-005

Page 3 of 5

\begin{tabular}{|c|c|c|c|c|c|c|c|c|c|c|c|c|c|c|c|}
\hline \multirow[t]{2}{*}{ Variables } & \multicolumn{5}{|c|}{ Both gender } & \multicolumn{5}{|c|}{ Females } & \multicolumn{5}{|l|}{ Males } \\
\hline & $\mathrm{N}$ & Min & Max & Mean & SD & & $\mathrm{N}$ & Min & Max & Mean & $\mathrm{N}$ & Min & Max & Mean & SD \\
\hline AGE & 211 & 16 & 45 & 23.58 & 4.95 & 123 & 16.00 & 45 & 23.74 & 5.36 & 88 & 18 & 43 & 23.35 & 4.34 \\
\hline STATURE & 211 & 149 & 190 & 167.55 & 9.1 & 123 & 149.00 & 190 & 163.17 & 7.64 & 88 & 156 & 190 & 173.66 & 7.3 \\
\hline $\mathrm{HL}$ & 92 & 16.4 & 22 & 19.24 & 1.18 & 55 & 17.4 & 21 & 18.77 & 0.85 & 37 & 16.4 & 22 & 19.92 & 1.27 \\
\hline $\mathrm{HB}$ & 93 & 6.1 & 11.2 & 9.43 & 0.82 & 56 & 6.10 & 10.8 & 9.03 & 0.71 & 37 & 8.3 & 11.2 & 10.04 & 0.6 \\
\hline 1ST DL & 96 & 5.1 & 8.4 & 6.49 & 0.62 & 56 & 5.10 & 8.4 & 6.27 & 0.52 & 40 & 5.2 & 7.8 & 6.81 & 0.61 \\
\hline 2ND DL & 96 & 5.7 & 9.2 & 7.18 & 0.57 & 56 & 5.80 & 8.15 & 6.98 & 0.43 & 40 & 5.7 & 9.2 & 7.46 & 0.63 \\
\hline 3RD DL & 95 & 6.1 & 9.9 & 7.97 & 0.64 & 56 & 6.60 & 9.2 & 7.77 & 0.49 & 39 & 6.1 & 9.9 & 8.25 & 0.73 \\
\hline 4TH DL & 96 & 5.2 & 9.3 & 7.39 & 0.59 & 56 & 6.40 & 8.45 & 7.2 & 0.43 & 40 & 5.2 & 9.3 & 7.65 & 0.69 \\
\hline 5TH DL & 96 & 3.7 & 7.54 & 5.9 & 0.59 & 56 & 4.60 & 7.54 & 5.77 & 0.48 & 40 & 3.7 & 7.5 & 6.08 & 0.69 \\
\hline
\end{tabular}

Table 1: Descriptive statistics of age (years), left hand dimensions (CM) of both genders, females and males.

\begin{tabular}{|c|c|c|c|c|c|c|c|c|}
\hline \multirow{3}{*}{ Variables } & \multicolumn{5}{|c|}{ Paired Differences } & \multirow{3}{*}{ Df } & \multirow{3}{*}{$\mathbf{T}$} & \multirow{3}{*}{ Sig. (2-tailed) } \\
\hline & & & & \multicolumn{2}{|c|}{$5 \%$ Confidence Interval of the Difference } & & & \\
\hline & Mean & Std. Deviation & $\begin{array}{l}\text { Std. Error } \\
\text { Mean }\end{array}$ & Lower & Upper & & & \\
\hline $\mathrm{HL}(\mathrm{F})-\mathrm{HL}(\mathrm{M})$ & -1.550 & 1.186 & 0.297 & - & -0.918 & -5.228 & 15 & 0.000 \\
\hline $\mathrm{HB}(\mathrm{F})-\mathrm{HB}(\mathrm{M})$ & -1.187 & 0.7549 & 0.195 & - & -0.769 & -6.088 & 14 & 0.000 \\
\hline $1^{\text {st }} \mathrm{DL}(\mathrm{F})-1^{\text {st }} \mathrm{DL}(\mathrm{M})$ & -0.681 & 0.526 & 0.124 & -0.942 & -0.419 & -5.488 & 17 & 0.000 \\
\hline $2^{\text {nd }} \mathrm{DL}(\mathrm{F})-2^{\text {nd }} \mathrm{DL}(\mathrm{M})$ & -0.467 & 0.557 & 0.132 & -0.745 & -0.189 & -3.544 & 17 & 0.002 \\
\hline $3^{\text {rd }} \mathrm{DL}(\mathrm{F})-3^{\text {rd }} \mathrm{DL}(\mathrm{M})$ & -0.678 & 0.646 & 0.157 & - & -0.346 & -4.326 & 16 & 0.001 \\
\hline $4^{\text {th }} \mathrm{DL}(\mathrm{F})-4^{\text {th }} \mathrm{DL}(\mathrm{M})$ & -0.536 & 0.506 & 0.119 & -0.788 & -0.285 & -4.500 & 17 & 0.000 \\
\hline $5^{\text {th }} \mathrm{DL}(\mathrm{F})-5^{\text {th }} \mathrm{DL}(\mathrm{M})$ & -0.418 & 0.493 & 0.116 & -0.664 & -0.174 & -3.603 & 17 & 0.002 \\
\hline
\end{tabular}

Table 2: Comparison of difference of variable in females and males of left hand dimensions.

\begin{tabular}{|c|c|c|c|c|c|c|c|c|c|}
\hline \multirow[t]{2}{*}{ Variables } & \multicolumn{3}{|c|}{ Both gender } & \multicolumn{3}{|c|}{ Females } & \multicolumn{3}{|c|}{ Males } \\
\hline & $\mathrm{N}$ & Min & Max & $\mathrm{N}$ & $\begin{array}{l}\text { Pearson } \\
\text { Correlation }\end{array}$ & Sig. (2-tailed) & $\mathrm{N}$ & Pearson Correlation & Sig. (2-tailed) \\
\hline $\mathrm{HL}$ & 211 & 16 & 45 & 55 & $0.638^{* *}$ & 0 & 37 & $0.610^{* *}$ & 0 \\
\hline $\mathrm{HB}$ & 211 & 149 & 190 & 56 & 0.166 & 0.223 & 37 & $0.431^{* *}$ & 0.008 \\
\hline 1ST DL & 92 & 16.4 & 22 & 56 & $0.409^{* *}$ & 0.002 & 40 & $0.528^{* *}$ & 0 \\
\hline 2ND DL & 93 & 6.1 & 11.2 & 56 & $0.465^{* *}$ & 0 & 40 & $0.594^{* *}$ & 0 \\
\hline 3RD DL & 96 & 5.1 & 8.4 & 56 & $0.482^{*+}$ & 0 & 39 & $0.570^{* *}$ & 0 \\
\hline 4TH DL & 96 & 5.7 & 9.2 & 56 & $0.472^{*+}$ & 0 & 40 & $0.633^{* *}$ & 0 \\
\hline 5TH DL & 95 & 6.1 & 9.9 & 56 & $0.397^{* *}$ & 0.002 & 40 & $0.511^{* *}$ & 0.001 \\
\hline \multicolumn{10}{|c|}{ HL: Hand Length; HB: Hand Breath; DL: Digit Length } \\
\hline
\end{tabular}

Table 3: Pearson correlation between stature with left hand dimensions in both genders put together, females and males. Correlation is significant at the 0.01 level (2-tailed) "Correlation is significant at the 0.05 level (2-tailed).

\begin{tabular}{|c|c|c|c|c|}
\hline Variables & Constant & $\begin{array}{c}\text { Regression } \\
\text { Coefficient }\end{array}$ & $\mathbf{R}^{\mathbf{2}}$ & $\mathbf{p}$ value \\
\hline $\mathrm{HL}$ & 66.603 & 5.161 & 0.528 & 0.000 \\
\hline $\mathrm{HB}$ & 111.841 & 5.733 & 0.324 & 0.000 \\
\hline $1^{\text {st }} \mathrm{DL}$ & 110.952 & 8.530 & 0.370 & 0.000 \\
\hline $2^{\text {nd }} \mathrm{DL}$ & 96.304 & 9.761 & 0.414 & 0.000 \\
\hline $3^{\text {rd }} \mathrm{DL}$ & 99.744 & 8.353 & 0.374 & 0.000 \\
\hline $4^{\text {th }} \mathrm{DL}$ & 97.296 & 9.347 & 0.409 & 0.000 \\
\hline $5^{\text {th }} \mathrm{DL}$ & 122.590 & 7.414 & 0.254 & 0.000 \\
\hline $1^{\text {st }} \mathrm{DL}$ & 85.207 & 5.089 & 0.505 & 0.000 \\
\hline $2^{\text {nd }} \mathrm{DL}$ & & 6.702 & & 0.000 \\
\hline \multicolumn{2}{|c|}{$\mathrm{HL}$} & \\
\hline
\end{tabular}

Table 4: Constant, Regression coefficient and Variation explained $\left(R^{2}\right)$ of left hand variables with Stature (dependent) variables in both genders. 


\begin{tabular}{|c|c|c|c|c|c|c|c|c|}
\hline Variables & Constant & Females Regression Coefficient & $\mathbf{R}^{2}$ & p-value & Constant & $\begin{array}{c}\text { Males Regression } \\
\text { Coefficient }\end{array}$ & $\mathbf{R}^{2}$ & p-value \\
\hline HL & 87.312 & 3.935 & 0.407 & 0 & 103.922 & 3.46 & 0.372 & 0 \\
\hline HB & & & & & 120.681 & 5.201 & 0.186 & 0.008 \\
\hline $1^{\text {st }} \mathrm{DL}$ & 135.252 & 4.154 & 0.167 & 0.002 & 129.577 & 6.438 & 0.279 & 0 \\
\hline $2^{\text {nd }} \mathrm{DL}$ & 121.164 & 5.752 & 0.216 & 0 & 121.355 & 6.985 & 0.353 & 0 \\
\hline $3^{\text {rd }} \mathrm{DL}$ & 121.149 & 5.168 & 0.232 & 0 & 124.544 & 5.927 & 0.325 & 0 \\
\hline $4^{\text {th }} \mathrm{DL}$ & 119.815 & 5.759 & 0.223 & 0 & 121.017 & 6.854 & 0.401 & 0 \\
\hline $5^{\text {th }} \mathrm{DL}$ & 135.865 & 4.404 & 0.158 & 0.002 & 139.546 & 3.801 & 0.261 & 0.001 \\
\hline
\end{tabular}

Table 5: Constant, regression coefficient and variation explained (R2) of left Hand variables with stature (dependent) variable in females and males.

\begin{tabular}{|c|c|c|c|c|c|c|c|c|c|c|c|c|}
\hline \multirow[t]{2}{*}{ Variables } & \multicolumn{4}{|c|}{ Both genders } & \multicolumn{4}{|c|}{ Females } & \multicolumn{4}{|c|}{ Males } \\
\hline & $\mathrm{R}$ & $\mathrm{R}^{2}$ & Adjusted $\mathrm{R}^{2}$ & SEE & $\mathrm{R}$ & $\mathrm{R}^{2}$ & Adjusted $\mathrm{R}^{2}$ & SEE & $\mathrm{R}$ & $\mathrm{R}^{2}$ & Adjusted $\mathrm{R}^{2}$ & SEE \\
\hline $\mathrm{HL}$ & 0.727 & 0.528 & 0.523 & 5.782 & 0.638 & 0.407 & 0.396 & 4.072 & 0.610 & 0.372 & 0.354 & 5.794 \\
\hline $\mathrm{HB}$ & 0.569 & 0.324 & 0.317 & 6.895 & & & & & 0.431 & 0.186 & 0.162 & 6.623 \\
\hline $1^{\text {st }} \mathrm{DL}$ & 0.608 & 0.370 & 0.364 & 6.911 & 0.409 & 0.167 & 0.152 & 4.845 & 0.528 & 0.279 & 0.260 & 6.416 \\
\hline $2^{\text {nd }} \mathrm{DL}$ & 0.644 & 0.414 & 0.408 & 6.666 & 0.465 & 0.216 & 0.201 & 4.702 & 0.594 & 0.353 & 0.336 & 6.076 \\
\hline $3^{\text {rd }} \mathrm{DL}$ & 0.617 & 0.380 & 0.374 & 6.876 & 0.482 & 0.232 & 0.218 & 4.654 & 0.570 & 0.325 & 0.307 & 6.288 \\
\hline $4^{\text {th }} \mathrm{DL}$ & 0.639 & 0.409 & 0.402 & 6.697 & 0.472 & 0.223 & 0.208 & 4.682 & 0.633 & 0.401 & 0.385 & 5.848 \\
\hline $5^{\text {th }} \mathrm{DL}$ & 0.504 & 0.254 & 0.246 & 7.523 & 0.397 & 0.158 & 0.142 & 4.873 & 0.511 & 0.261 & 0.242 & 6.492 \\
\hline $\begin{array}{l}1^{\text {st }} \mathrm{DL} \\
2^{\text {nd }} \mathrm{DL}\end{array}$ & 0.711 & 0.505 & 0.495 & 6.158 & & & & & & & & \\
\hline & & & & HL: & Length & Hand B & th, DL: Digit Le & & & & & \\
\hline
\end{tabular}

Table 6: $R, R^{2}$, Adjusted $R^{2}$, and $S E E$ of left variables in both genders, females and males.

has the highest values for the coefficient of determination $\mathrm{R}_{2}$ as 0.528 , $\mathrm{R}_{2}$ Adjusted as 0.523 and multiple correlation coefficient $\mathrm{R}$ as 0.727 with 5.782 as the SEE.

In the females, no multiple linear regression model was developed but the best simple linear regression model was developed using HL and this has highest values for the coefficient of determination as $R_{2}$ $0.407, \mathrm{R}_{2}$ Adjusted as 0.396 and multiple correlation coefficient $\mathrm{R}$ as 0.638 with a $4.072 \mathrm{SEE}$. In the males, it was not possible to develop multiple linear regression models. The best simple linear regression model was developed using 4 th DL. This very model has the coefficient of determination $\mathrm{R}_{2}$ as $0.401 ; \mathrm{R}_{2}$ adjusted as 0.385 and multiple correlation coefficient $\mathrm{R}$ as 0.633 with 5.848 SEE. The best simple linear regression equation developed for both genders together, females and males respectively are: stature both gender $=66.603+5.161(\mathrm{HL})$, stature female $=87.312+3.935(\mathrm{HL})$ and stature male $=121.017+6.854$ $\left(4^{\text {th }} \mathrm{DL}\right)$ i.e. when the explanatory variables were considered one after the other putting the value of $\mathrm{R}$ into consideration. Stature also could be estimated using other dimension of the left hand; the regression equations generated are in Tables 7 and 8 .

The maximum, minimum and the mean predicted values of stature through the regression function were similar to the maximum, minimum and mean observed values (Table 9). In females, the mean predicted value and the maximum predicted value underestimate the mean and the maximum observed values while the minimum predicted value overestimates the minimum observe values and these values were not significant. In the males the mean predicted values were similar to the mean observed value (Table 10).

\section{Discussion}

The results of the present study clearly indicate that stature can successfully be estimated from the somatometry of the left hand in condition where forensic experts are confronted with mutilated upper extremity segments or body part. Such information gotten can supplement the three (age, sex and race) of the "Big Four" of Forensic Anthropology.

The findings of this investigation also indicate that all the hand dimensions are positively and significantly corrected with stature except $\mathrm{HB}$ in females. This observation has the implication that $\mathrm{HB}$ cannot be used to estimate stature in Igbo females except when both sexes are put together. HL shows stronger correlation with stature than those of other hand dimensions. This observation is confirmed by lower SEE as well as high value of $\mathrm{R}, \mathrm{R}_{2}$, and Adjusted $\mathrm{R}_{2}$ for HL. It means that the regression equation generated using $\mathrm{HL}$ in both genders together and females give high degree of reliability and accuracy than those of other hand dimensions. In males reliability and accuracy was highest using $4^{\text {th }}$ DL.

The present study also shows that the multiple linear regression equation obtained using $1^{\text {st }} \mathrm{DL}$ and $2^{\text {nd }} \mathrm{DL}$ in both genders performed better than the simple linear regressions generated for the male or females. This statement is also proved by the values of $\mathrm{R}, \mathrm{R}_{2}$, and Adjusted $\mathrm{R}_{2}$, i.e. $(0.711,0.505$, and 4.95$)$ respectively, see Table 6 .

Over the decade, close relationships between stature and dimensions of various body segments have been reported and the results are frequently applied in anthropometric studies and medicolegal investigations $[1,2,4,7,19,33]$ the application of such result must be population specific since genetics, environment and even nutrition influences stature $[12,35,36]$, and this is in agreement with the present study [3]. Studied subjects in Delhi and found accurate or near accurate correlation between stature and length of fingers. They used independent linear regression equations and suggested that results are statistically significant. From their data it is evident that the index finger is best for the prediction of stature. In this present study, the $2^{\text {nd }}$ digit length was the best to estimate stature in both gender together while the $3^{\text {rd }}$ and 4 th digit lengths was the best to predict stature respectively 
Citation: Ekezie J, Anibeze CIP, Anyanwu GE, Uloneme GC (2015) Prediction of Stature from Somatometry of the Left Hand in Igbos, Nigeria. J Forensic Res S1: 005 doi:10.4172/2157-7145.S3-005

Page 5 of 5

\section{Regression equation}

Both Genders

Stature $=66.603+5.161(\mathrm{HL})$

Stature $=111.841+5.733(\mathrm{HB})$

Stature $=110.952+8.530(1 \mathrm{ST} D \mathrm{DL})$

Stature $=96.304+9.761(2 \mathrm{ND} D \mathrm{DL})$

Stature $=99.744+8.353(3 R D D L)$

Stature $=97.296+9.347(4 \mathrm{TH} \mathrm{DL})$

Stature $=122.590+7.414(5 \mathrm{TH} \mathrm{DL})$

Stature $=85.207+5.089(1 S T$ DL)+6.702(2ND DL)

HL: Hand Length, HB: Hand Breath, DL: Digit Length

\begin{tabular}{|l|}
\hline ISEE \\
\hline 5.78192 \\
\hline 6.89491 \\
\hline 6.91076 \\
\hline 6.66582 \\
\hline 6.87608 \\
\hline 6.69735 \\
\hline 7.52301 \\
\hline 6.15842 \\
\hline
\end{tabular}

ISEE

6.89491

6.91076

6.87608

6.15842

Table 7: Regression Equations for estimation of Stature in both genders using left dimensions.

\begin{tabular}{|c|c|c|}
\hline $\begin{array}{c}\text { Regression equation } \\
\text { Females }\end{array}$ & $\mathbf{\pm S E E}$ & $\begin{array}{c}\text { Regression equation } \\
\text { Males }\end{array}$ \\
\hline Stature=87.312+3.935(HL) & 4.072 & Stature=103.922+3.460(HL) \\
\hline Stature=135.252+4.154(1ST DL) & 4.845 & Stature=120.681+5.201(HB) \\
\hline Stature=121.164+5.752(2ND DL) & 4.702 & Stature=129.577+6.438(1ST DL) \\
\hline Stature=121.149+5.168(3RD DL) & 4.654 & Stature=121.355+6.985(2ND DL) \\
\hline Stature=119.815+5.759(4TH DL) & 4.682 & Stature=124.544+5.927(3RD DL) \\
\hline Stature=135.865+4.404(5TH DL) & 4.873 & Stature=121.017+6.854(4TH DL) \\
\hline & \multicolumn{2}{|c|}{ Stature=139.546+3.801(5TH DL) } \\
\hline
\end{tabular}

Table 8: Regression Equations for estimation of Stature in females and males using left hand dimensions.

\begin{tabular}{|c|c|c|c|c|c|c|}
\hline \multicolumn{2}{|c|}{ Observed Value } & Minimum & Maximum & Mean & Std. Deviation & $\mathbf{N}$ \\
\hline \multirow{2}{*}{ Value } & $\mathrm{HL}$ & 149.00 & 190.00 & 167.55 & 9.10 & 211 \\
\hline & $\mathrm{HB}$ & 151.25 & 180.15 & 165.88 & 6.10 & 92 \\
\hline \multirow{6}{*}{ Predicted Value For: } & $1^{\text {st }} \mathrm{DL}$ & 146.82 & 176.06 & 165.90 & 4.75 & 93 \\
\hline & $2^{\text {nd }} \mathrm{DL}$ & 154.46 & 182.61 & 166.35 & 5.27 & 96 \\
\hline & $3^{\text {rd }} \mathrm{DL}$ & 151.94 & 186.11 & 166.35 & 5.58 & 96 \\
\hline & $4^{\text {th }} \mathrm{DL}$ & 150.69 & 182.43 & 166.29 & 5.36 & 95 \\
\hline & $5^{\text {th }} \mathrm{DL}$ & 145.90 & 184.23 & 166.35 & 5.54 & 96 \\
\hline & $\begin{array}{c}1^{\text {st }} D L \\
2^{\text {nd }} D L\end{array}$ & 150.03 & 178.49 & 166.35 & 4.36 & 96 \\
\hline
\end{tabular}

Table 9: Minimum, Maximum, Mean and standard deviations of the predicted Values of stature by regression functions with left hand variables in both genders.

\begin{tabular}{|c|c|c|c|c|c|c|c|c|c|c|}
\hline \multirow{2}{*}{ Observed Value } & \multicolumn{5}{|c|}{ Females } & \multicolumn{5}{|c|}{ Males } \\
\hline & Mini & Max & Mean & SD & $\mathbf{N}$ & Min & Max & Mean & SD & $\mathbf{N}$ \\
\hline $\mathrm{HL}$ & 149.00 & 190.00 & 163.17 & 7.64 & 123 & 156.00 & 190.00 & 173.66 & 7.30 & 88 \\
\hline $\mathrm{HB}$ & 155.78 & 169.94 & 161.17 & 3.34 & 55 & 160.67 & 180.05 & 172.87 & 4.39 & 37 \\
\hline $1^{\text {st }} \mathrm{DL}$ & & & & & & 163.85 & 178.93 & 172.88 & 3.12 & 37 \\
\hline $2^{\text {nd }} D L$ & 156.44 & 170.15 & 161.29 & 2.15 & 56 & 163.05 & 179.79 & 173.43 & 3.94 & 40 \\
\hline $3^{\text {rd }} \mathrm{DL}$ & 154.52 & 168.04 & 161.29 & 2.45 & 56 & 161.17 & 185.61 & 173.43 & 4.43 & 40 \\
\hline $4^{\text {th }} \mathrm{DL}$ & 155.26 & 168.69 & 161.29 & 2.53 & 56 & 160.70 & 183.22 & 173.46 & 4.30 & 39 \\
\hline $5^{\text {th }} \mathrm{DL}$ & 156.67 & 168.48 & 161.29 & 2.48 & 56 & 156.66 & 184.76 & 173.43 & 4.72 & 40 \\
\hline & 156.12 & 169.07 & 161.29 & 2.09 & 56 & 160.16 & 181.32 & 173.43 & 3.81 & 40 \\
\hline
\end{tabular}

Table 10: Minimum, Maximum, Mean and standard deviations of the predicted Values of stature by regression functions with left hand variables in females and males.

in females and males because of the values of $\mathrm{R}$ and SEE [37-40]. Reported for Japanese women a correlation ( $\mathrm{r}$ ) of proximal phalange and stature ranging from 0.521 to 0.696 . The regression formulae possessed standard errors ranging from 3.59 to $4.27 \mathrm{~cm}$. In this study, the correlation of the female's digit lengths with stature ranged from 0.397 to 0.638 while the regression formula possessed SEE ranging from 4.702 to $4.873 \mathrm{~cm}$. Although our dimensions for digit lengths incorporated both the distal, middle and part of the proximal phalanx; the upper limits of these values ( $r$, and SEE) are comparable with the study above.

Studies $[4,5,7,8,37]$ have estimated stature from hand length and phalange length and also reported sexual dimorphism in mean hand length. Regression equations were generated. The mean stature in the males was higher as compared to that of the females in such studies. 
Citation: Ekezie J, Anibeze CIP, Anyanwu GE, Uloneme GC (2015) Prediction of Stature from Somatometry of the Left Hand in Igbos, Nigeria. J Forensic Res S1: 005 doi:10.4172/2157-7145.S3-005

Page 6 of 5

These findings are congruent with that of this study. Comparing this study with the same isolated genetic population in our previous study using right hand dimensions [2], we observed that the values of $\mathrm{R}$ for the various left hand dimensions used to test model adequacy were higher in this present study. Also this study indicated lower SEE than that of our previous study. This means that left hand dimensions are more adequate to estimate stature in the same population than the right hand dimensions.

\section{Conclusion}

The best dimension to predict stature from the left hand somatometry of the study population is hand length followed by $1^{\text {st }}$ and $2^{\text {nd }}$ digit lengths. Also hand length provides the precise means of estimating stature in the females, this is followed by $3^{\text {rd }}$ digit length. In males, $4^{\text {th }}$ digit length is the best followed by hand length. The regression formula generated in this study will be of utmost help to Anatomists, Anthropologist, Archaeologist and Forensic experts.

\section{Acknowledgements}

The authors are grateful to all the subjects for their cooperation and patience since without such cooperation this study would not have seen the light of the day.

\section{References}

1. Krishan K, Vij K (2007) Diurnal variation of stature in three adults and one child Kamla Raj Enterprises, Anthropologist 9: 113-117.

2. Jervas E, Ikechukwu PAC, Chinedu AF, Emeka AG, Kingsely OC, et al. (2014) Stature estimation using right digits and palm lengths in Igbo population, Nigeria. Ann Bioanthropology 2: 23-28.

3. Tyagi AK, Kohli A, Verma SK, Aggarwal BBL (1999) Correlation between stature and fingers length. Inter J Med Toxi and Legal Med 1: 20-22.

4. Ilayperuma I, Nanayakkara G, Palahepittiya N (2009) Prediction of stature based on the hand length. Galle Med J 14: 15-18.

5. Jasuja OP (2004) Estimation of stature from hand and phalange length. JIAFM 26: $100-106$.

6. Rastogi P, Yoganarasimha $\mathrm{K}$ (2008) Stature estimation using palm length in Indian population. Inter J Med Toxi \& Legal Medb 11: 2.

7. Danborno B, Adebisi SS, Adelaiye AB, Ojo SA (2009) Estimation of Height and weight from the Lengths of Second and Fourth Digits in Nigerians. Inter J. Forensic Sci 3: 2

8. Sanli SG, Kizilkanat ED, Boyan N, Ozsahin ET, Bozkir MG, et al. (2005) Stature estimation based on hand length and foot length. Clin Anat 18: 589-596.

9. Manpreet K, Singh B, Mahajan A, Khurana BS, Kaur A, et al. (2013) Anthropometric Measurements of hand length for estimation of stature in North Indians Inter. J App Pharm Tech 4: 251-255.

10. Abdel-Malek AK, Ahmed AM, el-Sharkawi SA, el-Hamid NA (1990) Prediction of stature from hand measurements. Forensic Sci Int 46: 181-187.

11. Kalia S, Shetty SK, Patil K, Mahima VG (2008) Stature estimation using odontometry and skull anthropometry. Indian J Dent Res 19: 150-154.

12. Bhatnagar DP, Thapar SP, Batish MK (1984) Identification of personal height from the somatometry of the hand in Punjabi males. Forensic Sci Int 24: 137 141.

This article was originally published in a special issue, Analytical Applications in Forensic Sciences handled by Editor(s). Harvey Hou Department of Physical Sciences, Alabama State University, USA
13. Gruspier KL, Pollanen MS (2000) Limbs found in water: investigation using anthropological analysis and the diatom test. Forensic Sci Int 112: 1-9.

14. Kanchan T, Rastogi $P$ (2009) Sex determination from hand dimensions of North and South Indians. J Forensic Sci 54: 546-550.

15. Saxena SK (1984) A study of correlations and estimation of stature from hand length, hand breadth and sole length. Anthropol Anz 42: 271-276.

16. Meadows L, Jantz RL (1992) Estimation of stature from metacarpal lengths. $J$ Forensic Sci 37: 147-154.

17. Shintaku K, Furuya $Y(1990)$ [Estimation of stature based on the proximal phalangeal length of Japanese women's hands]. J UOEH 12: 215-219.

18. Duyar I, Pelin C (2003) Body height estimation based on tibia length in different stature groups. Am J Phys Anthropol 122: 23-27.

19. El-Meligy MM, Abdel-Hady RH, Abdel-Maaboud RM, Mohamed ZT (2006) Estimation of human body built in Egyptians. Forensic Sci Int 159: 27-31.

20. Zeybek G, Ergur I, Demiroglu Z (2008) Stature and gender estimation using foot measurements. Forensic Sci Int 181: 54.

21. Jibonkumar, Lilinchandra (2006) Estimation of stature using different facia measurements among the Kabui Naga of Imphal valley, Manipur. Kamla Raj Enterprises, Anthropologist 8: 1-3

22. Fessler DM, Haley KJ, Lal RD (2005) Sexual dimorphism in foot length proportionate to stature. Ann Hum Biol 32: 44-59.

23. Ilayperuma I (2010) On the prediction of personâs stature from crania dimensions. Int J Morphol 28: 1135-1140.

24. Krishan K (2008) Estimation of stature from cephalo-facial anthropometry in north Indian population. Forensic Sci Int 181: 52

25. Krishan K, Kumar R (2007) Determination of stature from cephalo-facial dimensions in a North Indian population. Leg Med (Tokyo) 9: 128-133.

26. Sahni D, Sanjeev, Sharma P, Harjeet, Kaur G, et al. (2010) Estimation of stature from facial measurements in northwest Indians. Leg Med (Tokyo) 12: 23-27.

27. Ozaslan A, Işcan MY, Ozaslan I, Tuğcu H, Koç S (2003) Estimation of stature from body parts. Forensic Sci Int 132: 40-45

28. Patel SM, Sha VG, Patel SV (2007) Estimation of height from measurement of foot length in Gujarat region. J. Ant. Soc. India 56: 25-27.

29. Ozaslan A, Koç S, Ozaslan I, Tuğcu H (2006) Estimation of stature from upper extremity. Mil Med 171: 288-291.

30. Kanchan T, Menezes RG, Moudgil R, Kaur R, Kotian MS, et al. (2008) Stature estimation from foot dimensions. Forensic Sci Int 179: 241.

31. van der Lugt C, Nagelkerke NJ, Maat GJ (2005) Study of the relationship between a person's stature and the height of an ear imprint from the floor. Med Sci Law 45: 135-141.

32. Nandy A (2001) Principles of forensic medicine. (2ndedn) Calcutta: New Central Book Agency 86-89.

33. Parikh CK (2002) Parikh's Textbook of Medical Jurisprudence and Toxicology. 6th Ed. New

34. Dawnson B, Trapp RG (2004) Basic and clinical biostatistics. (4thedn) New York: McGraw-Hill Companies, Inc 1-438.

35. Landau S, Everitt BS (2004) A handbook of statistical analyses using SPSS Boca Raton: Chapmann and Hall/CRC 1-354.

36. Eveith P, Tanner J (1976) World variation in human growth. Cambridge university press, Cambridge 157

37. Danborno B, Elupko A (2008) Sexual dimorphism in hand and foot length indices, stature-ratio and relationship to height in Nigerians. Int. J. Foren Sc 1.

38. Butler MG, Haynes JL, Meaney FJ (1991) Anthropometric study with emphasis on hand and foot measurements in the Prader-Willi syndrome: sex, age and chromosome effects. Clin Genet 39: 39-47.

39. Davies BT, Benson AK, Courtney A, Minto I (1980) A comparison of hand anthropometry of females in three ethnic groups. Ergonomics 23: 179-182.

40. Lohman TG, Roche A, Martorell R (1988) Anthropometric Standardization Reference Manual. Library of Congress. Printed in USA. 